Arch. histol. jap. Vol. 28, n. 4 (1967)

p. $425-447$

Department of Anatomy (Prof. E. YAmada), Faculty of Medicine, Kyushu

University, Fukuoka, Japan

\title{
Studies on the Fine Structure of Red and White Fin Muscles
} of the Fish (Carassius auratus)

\section{Hidenori Nishinara （西 原 英 徳）}

Received August 25, 1967

It has been known for long time that there are, due to their colours, red and white muscle fibres in skeletal muscles of many animals (KüHnE 1865, Needham 1926).

In 1874, RANVIER first showed a correlation between the contraction speeds of red and white fibres and their histological features and suggested that red fibres have a slower, more prolonged contraction than white ones.

Many observations on the fibre types of muscles demonstrated the differences between red and white fibres morphologically and functionally. They were sometimes called dark and light, thin and thick or protoplasm rich and protoplasm poor fibres by several investigators (NeEdham 1926, Denny-Brown 1929 and others).

KR ÜGER (1949) divided frog and other vertebrate muscle fibres into Felderstruktur and Fibrillenstruktur types by examining the difference in size and shape of the myofibrils in stained transverse sections of the fibres.

Physiological evidence also showed two functionally different types of striated muscle fibre which occur in the frog, namely the fast twich and slow tonic muscle fibres (Kuffler and Vaughan Williams 1953).

Thereafter, the clear-cut fine structural distinction between the slow and fast fibres of the frog was established by Peachey and Huxley (1962) who dissected single fibres from the iliofibularis muscles of frogs, determined their physiological type by eletrical stimulation and subsequently examined these fibres by electron microscopy.

Similar observations in mammalian extraocular muscles showed that Fibrillenstructur fibre with a single en plaque nerve ending corresponded to the fast fibre while Felderstruktur fibre with multiple en grappe endings was distributed along its length to the slow fibre by phase contrast and electron microscopy (Hess 1961) and with intracellular microelectrodes (Hess and Pillar 1963).

From the histochemical studies, the skeletal muscles of mammals were classified into two types, red and white (Naghmias and Padykula 1958, Dubowitz and Pearse 1960), or three types, A, B, and C (Stein and Padykula 1962), and red, white and intermediate (OGATA and Mori 1964) on the basis of the variation in the oxidative enzyme activity of the individual fibres to imply their different metabolic activities.

As is well known, there are two main types of muscle fibre in fish myotome, that is, the red fibres which form a thin lateral superficial sheet just under the skin, and the white fibres which make up the underlying mass of the myotome and they are clearly distinct from one another. Yet, closer observations revealed that in the transitional part of the red and white muscle, the intermediate type of fibres was visible, 
but it was less abundant than the red or white fibres (F 1962, Ogata and Mori 1964, Bone 1966).

From the accumulated observations, however, there appears to be considerable variations in the functional or morphological properties even in the one type of fibre.

Red muscle has often been used as an analogous term for slow muscle but at other times, red muscle has been considered as a fast muscle (BERGMAN $1964 \mathrm{a}, \mathrm{b}$, Gauthier and Padykula 1966, Gheng and Breinin 1966).

Takeuchi (1959) and Andersen, JAnsen and Loyning (1963) studied the physiological properties in the red and white muscle of fish and they postulated that the red muscle of fish had some analogous properties with the slow muscle fibre of the frog.

Recently more extensive studies were made on the physiological properties of the pectoral fin muscle and the abdominal fin muscle in sea water fishes (HAGIwARA and TAKAHASH 1967) and in fresh water fish, crucian carp (Hidaka and Toida $1967 \mathrm{a}, \mathrm{b}$, Hidaka and Kuriyama 1967).

The pectoral fin muscle of the crucian carp appears "red" and the abdominal fin muscle "pale" to the naked eye.

The electrophysiological properties of the cell membrane of both muscles are exceedingly different and action potentials are generated in the white muscle but very rarely in the red one.

It is the purpose of the present investigation to study with an electron microscope the fine structure of the red and white muscles of the crucian carp. At the same time, some informations on the structure of the motor endings on both fibres will be described.

\section{Materials and methods}

Young adult crucian carp (Carassius auratus) were used for this study. The red pectoral fin muscles (M. levator pinnae pectoralis) and the white abdominal fin muscles (M. levator pinnae lateralis abdominis) of unanesthetized crucian carp were exposed and pinned onto dental wax to prevent them from contracting at the beginning of fixation. They were first fixed in a $4 \%$ glutaraldehyde buffered with phospate or s-Collidine at $\mathrm{pH} 7.4$ for two hours at room temperature, then washed briefly in the same buffer, and further fixed for two hours in a $2 \%$ osmium tetroxide buffered with phosphate or s-Collidine at $\mathrm{pH} 7.4$ respectively. They were also fixed by KARNOvsKy's (1965) cacodylate buffered formaldehyde-glutaraldehyde method following s-Collidine buffered osmification. Some other tissues were fixed in a $2 \%$ osmium tetroxide buffered with s-Collidine at $\mathrm{pH} 7.4$ for two hours (BENNETT and L.UFT 1959). After dehydration in a series of ice-cold graded acetones, the specimens were embedded in Epon 812 (LUFT 1961). In some cases, the materials were stained with a $2 \%$ aqueous solution of uranyl acetate for one hour before dehydration (MERGer and Birbeck 1966).

Thin sections for electron microscopy were cut with glass knives on a PorterBlum microtome and stained with lead acetate (LUFT, personal communication) or doubly stained with lead and uranyl acetate. The sections were examined in a Hitachi HU-11A electron microscope. Thick sections (about $1.5 \mu$ ) were stained with $0.5 \%$ toluidine blue (ҮАмамото 1963) and examined with a light microscope. 
Images of transverse sections of toluidine blue stained material were projected to achieve an enlargement for measurement of the fibre diameter in red and white fibres. The outlines of muscle fibres in the enlarged images were traced and the fibre diameter was calculated from the planimetric measurements on the tracings.

The specimens used for the present study were only the surface layers of both red and white muscles to correlate with the physiological observations.

\section{Results}

Distinctive morphological differences between red and white fibres can be clearly detected by a light microscopic examination of the transverse sections stained with toluidine blue.

When stained with toluidine blue, in red fibres (Fig. 1) a very dark blue stain at

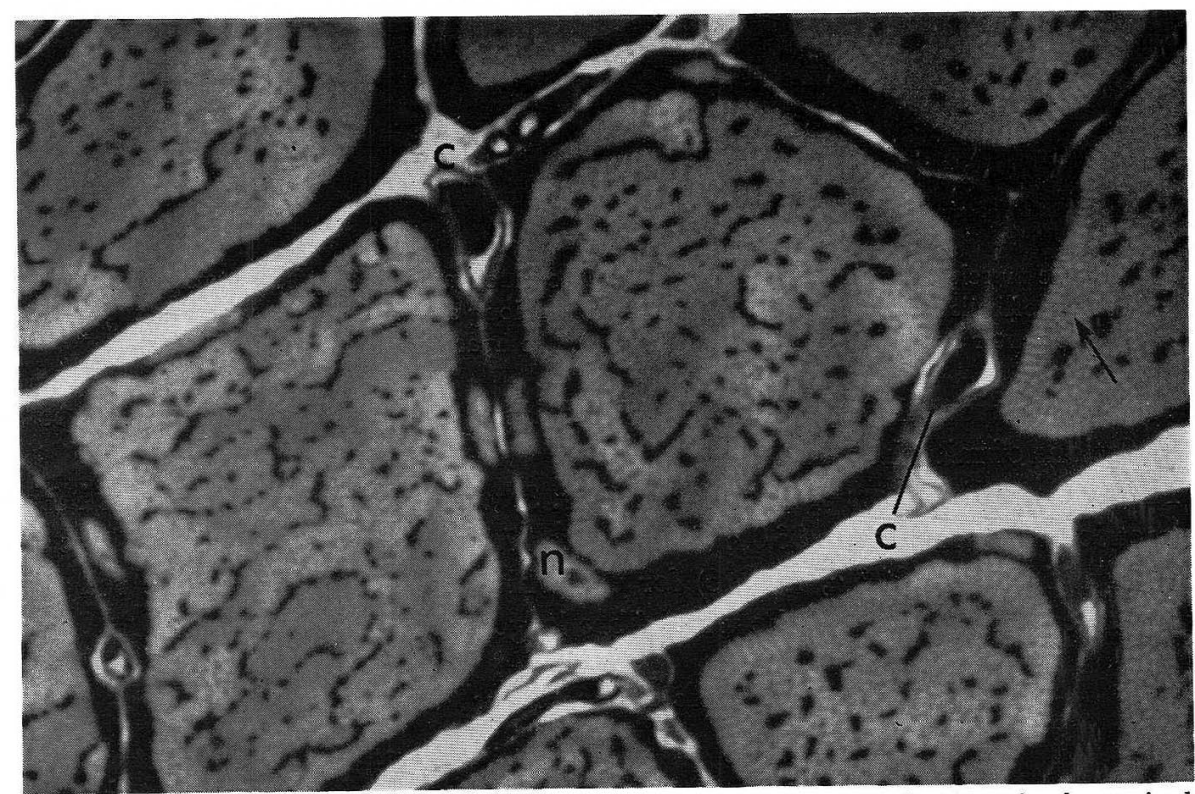

Fig. 1. Red muscle fibres in cross section, toluidine blue stain. Very darkly stained marginal zones of the fibres and dark dots within the fibres are seen. Note the shape of peripheral myofibrils and inner fibrils (arrow). $n$ Nuclei, $c$ capillary. $\times 1,000$

the marginal zone of the fibres and scattered dark dots within the fibres can be seen. These broad marginal zones extend continuously around the fibre but are thin at a few places where capillaries occur. The nuclei are located in the peripheral layer of the fibre and are enveloped in the dark stained marginal zones. The peripheral myofibrils are found to be rectangular in shape and are arranged in a radial direction in the fibre. Almost all inner myofibrils are polygonal. In white fibres (Fig. 2), on the other hand, larger dimensions of the fibre, no darkly bluc stained peripheral zone of the fibres, a sparsity of dark blue stained dots within the fibres, longer and flat ribbon-like forms of the peripheral myofibrils and a poor supply of capillaries are conspicuous. Since mitochondria can be demonstrated clearly with the toluidine 


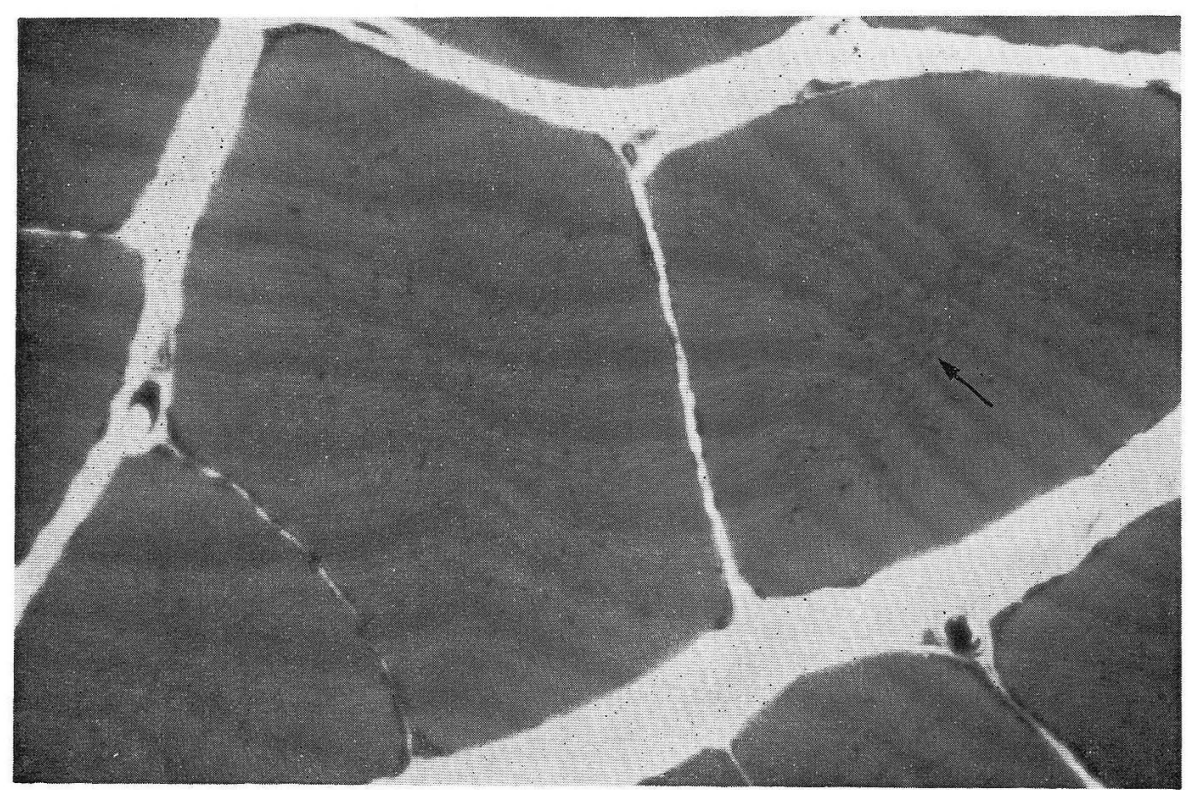

Fig. 2. White muscle fibres in cross section, toluidine blue stain. Darkly blue stained parts are few. The myofibrils in the periphery of the fibres are long and ribbon-likc whereas those in the center are polygonal in shape (arrow). Compare with Figure $1 . \times 1,000$

blue stain (Yамамото 1963), the darkly bluc staincd zones or dots are thought to be accumulations of mitochondria.

The average diameters of both fibres (Fig. 3) which have been calculated from planimetric measurments are $36.0 \mu$ (from 7.8 to $77.1 \mu, \mathrm{n}=489$ ) for the red fibres and $49.4 \mu$ (from 16.1, to $104.3 \mu, \mathrm{n}=376$ ) for the white ones. Therefore, the red fibre may be called small fibre and the white fibre large one.

Distributions of fiber diameter
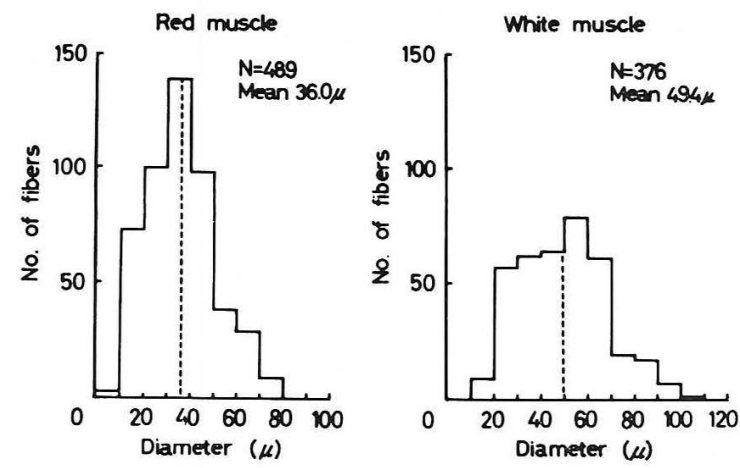

Fig. 3. Distribution of fibre diameter. The histograms were calculated from planimetric measurements of the images of transverse sections of the red and white fibres. Dotted lines indicate the average diameters of the fibres. 


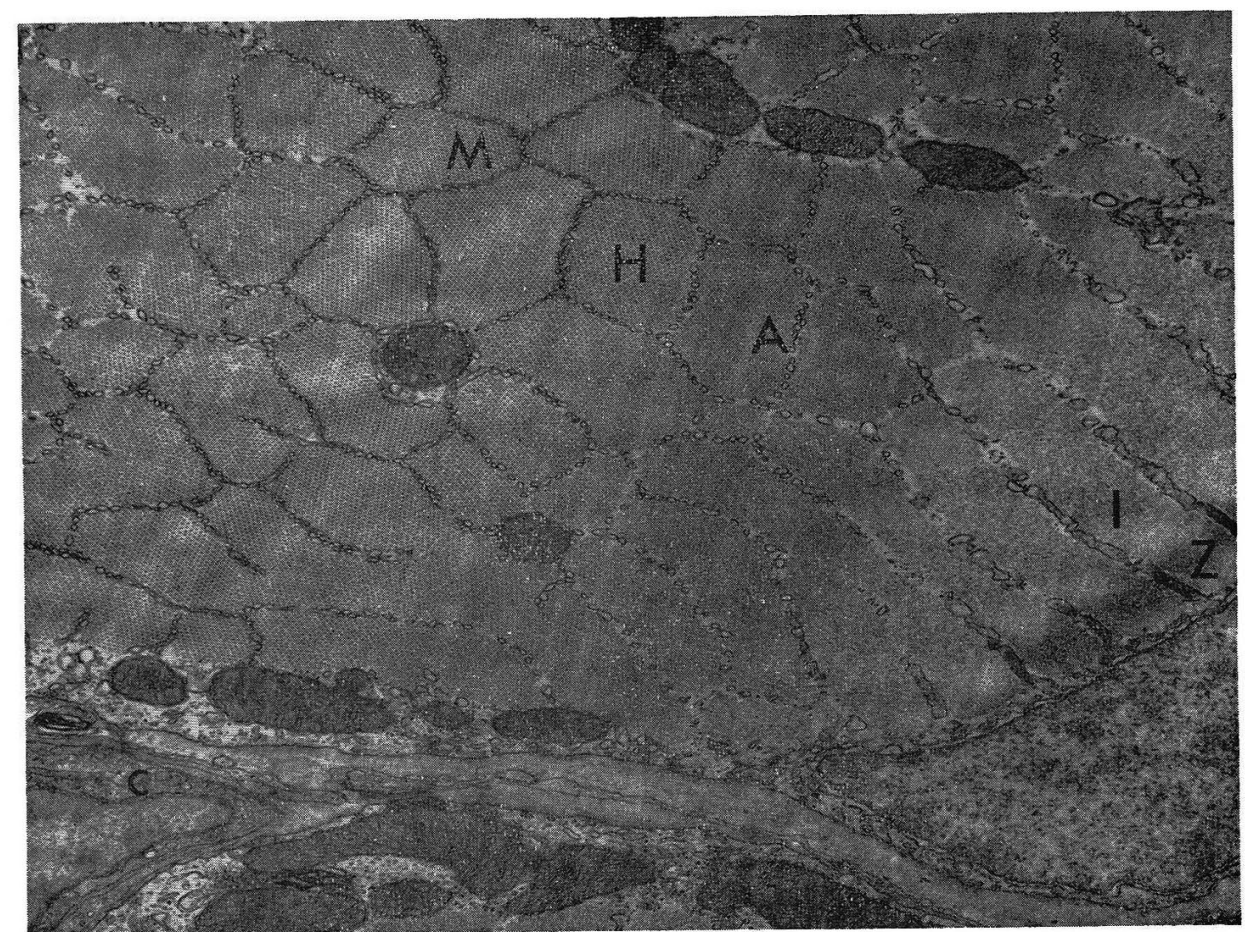

Fig. 4. Red fibre in cross section. Rectangular myofibrils in the peripheral portion of the fibre and polygonal ones in the inner are seen. Each fibrils are well delineated by sarcoplasmic elements. The subsarcolemmal accumulation of mitochondria is not remarkable. A capillary $(c)$ is seen at the under left corner of the figure. Note the disposition of the myofilaments and the profiles of the sarcoplasmic reticulum in the different bands of the sarcomere. $Z \mathrm{Z} \mathrm{line,} I \mathrm{I}$ band, $A$ A band, $H \mathrm{H}$ zone, $M \mathrm{M}$ line. s-Collidine buffered $\mathrm{OsO}_{4}$ fixation. $\times 13,000$

In electron micrographs of transverse sections of the red fibres (Fig. 4, 5), one can see such appearances as have been described above basing on the light microscopic observations. The subsarcolemmal accumulation of mitochondria (Fig. 5) coincides with the dark blue stained peripheral portion of fibres in the light micrograph and the myofibrils are enclosed by a sarcoplasm which contains large numbers of mitochondria, rich deposits of glycogen and ribosomes. Sometimes fat droplets are found here and there among the mitochondria. The mitochondrial accumulation under the sarcolemma in the vicinity of a capillary is either inconspicuous (Fig.4) or lacking, and in such places the sarcolemma looks depressed to the myofibrils beneath it (Fig. 6).

The array of myofibrils (Fig. 4) is the same as has been pointed out in the light microscopic examination and is similar to that found in other fish muscles (NAKAJrMA 1962, Bergman 1964a, Franzini-Armstrong and Porter 1964). In transverse sections through various bandings of several myofibrils, one observes the myofibrils well delineated by sarcoplasmic clements and the disposition of the myofilaments in the different bands of the sarcomere (Fig. 4, 12, 13).

The profiles of sarcoplasmic reticulum (Porter and Palade 1957) including transverse tubule or T system (ANDERsson-CEDERGREN 1959) are different in shape and 


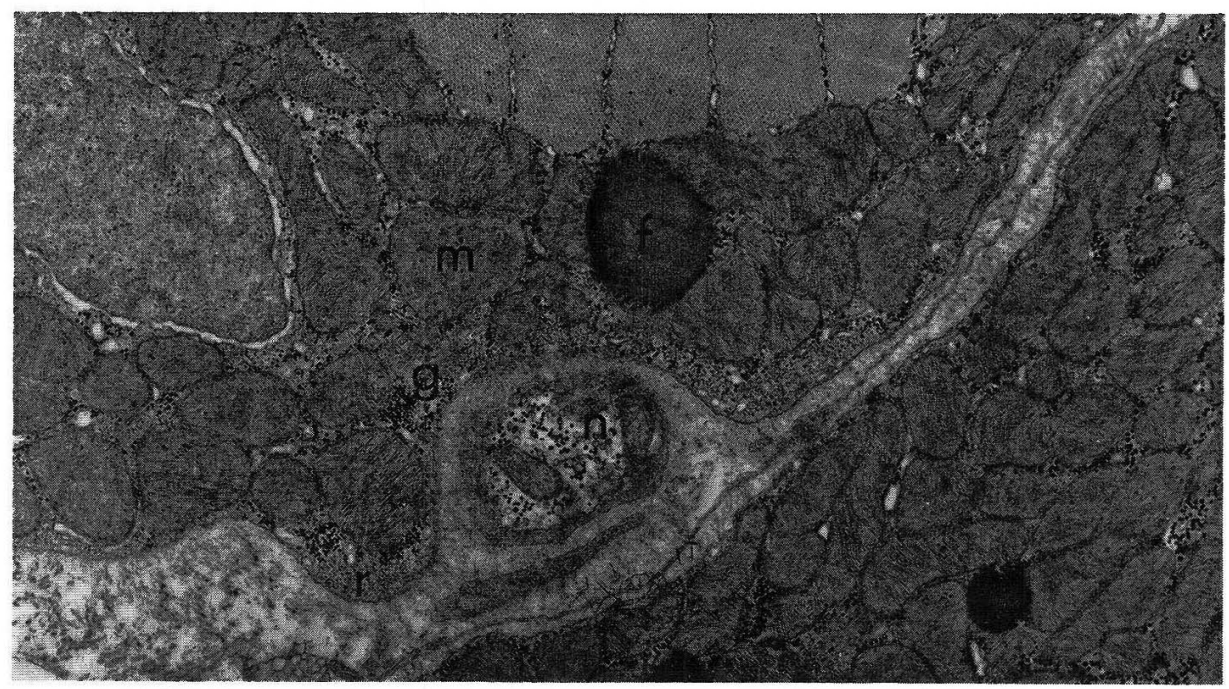

Fig. 5. Red fibre in cross section. The subsarcolemmal accumulation of mitochondria $(m)$ is shown. At the periphery of the fibre, there are rich deposits of glycogen $(g)$, groups of ribosomes $(r)$ and some drops of fat $(f) . n$ Nerve fibre. Phosphate buffered $\mathrm{OsO}_{4}$ fixation. $\times 13,000$

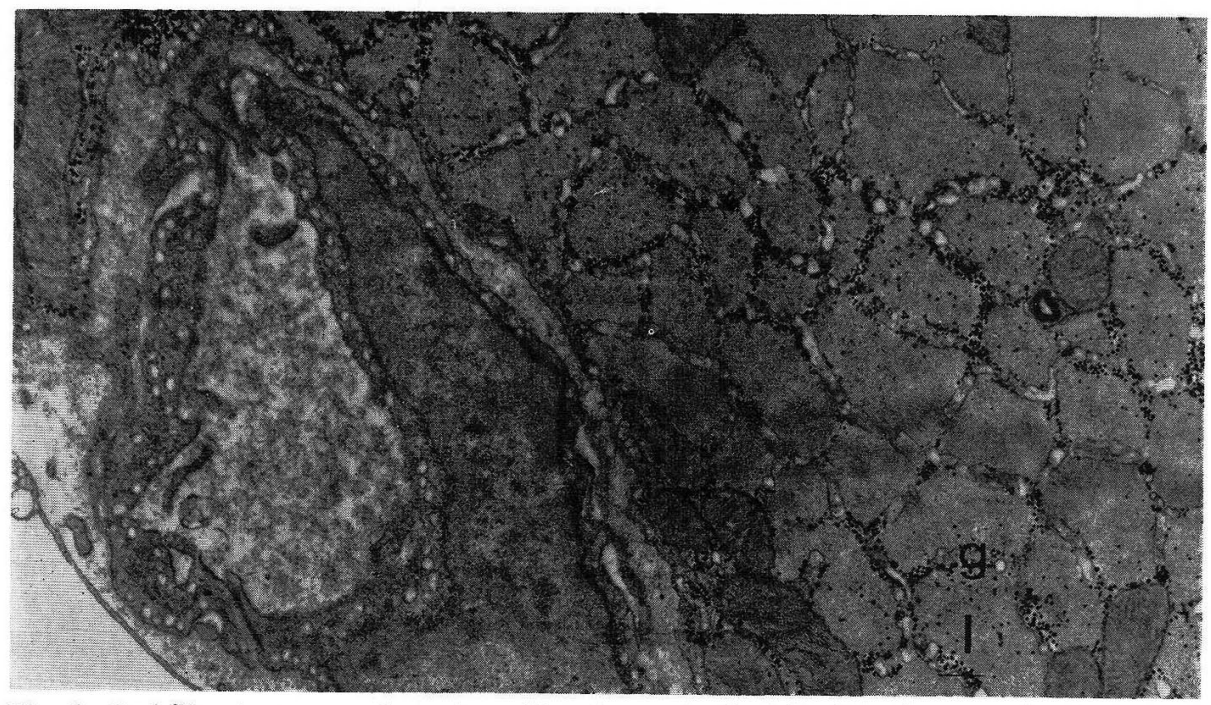

Fig. 6. Red fibre in cross section. A capillary is seen in the left of the figure resting in troughlike depression of the sarcolemma. Glycogen $(g)$ is rich at the I band region $(I)$. Phosphate buffercd $\mathrm{OsO}_{4}$ fixation. $\times 13,000$

range according to various bandings of the sarcomere (Fig. 4, 12, 13). They are elongated with some dense content at the $\mathrm{Z}$ line, elongated and rather dilated at the $\mathrm{I}$ band and tubular at the $\mathrm{A}$ band and $\mathrm{M}$ line. The few tubular profiles, from the A band towards the $\mathrm{M}$ line, turn into a more continuous grouping of vesicles surrounding each myofibril particularly at the $\mathrm{M}$ line, where sarcoplasmic reticulum 
forming an intricate meshwork is suggested.

Glycogen are rich at the region of $I$ band as well as under the sarcolemma when phosphate buffered fixatives are used (Fig. 5,6). In Gollidine-buffered materials (Fig. 4), glycogen in the subsarcolemmal cytoplasm and the I band region is disperse and not particularly dense in lead staining, but the mitochondria have dense matrix (also compare Figure 6 with Figure 14) as described by Wood and LuFt (1965). In addition, using double fixation of glutaraldehyde and osmium tetroxide buffered with s-Collidine alone, almost all glycogen deposits disappear (Fig. 12). In contrast to the red fibre, in white fibres as in other fish white muscle (Franzini-Armstrong and Porter 1964), there are a few mitochondria and some glycogen in a small

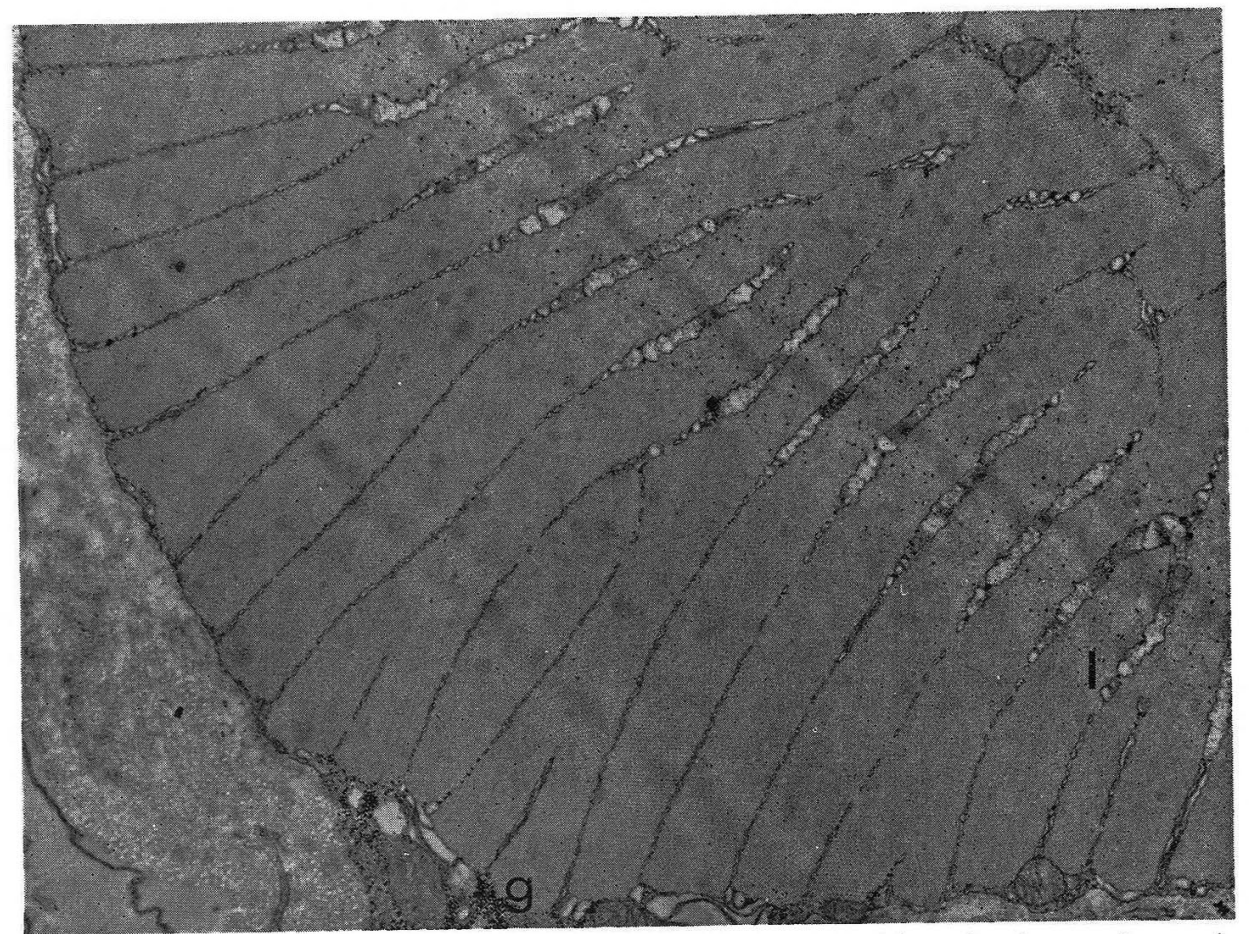

Fig. 7. White fibre in cross section. No accumulation of mitochondria under the sarcolemma is seen. Therc is some glycogen $(g)$ in the scanty sarcoplasm. Glycogen is also sparse in the $I$ band reigon $(I)$. Peripheral myofibrils appear in flat and long ribbon-like forms. $\times 11,000$

amount of sarcoplasm around the myofibrils at the marginal zones of the fibres. Glycogen in the I band region is also sparse and the fat droplets are rare. Peripheral myofibrils appear mostly in longer ribbon-like forms, as in the toad fish swimbladder muscle (FAwGETT and REVEL 1961), compared with those in the red fibres and the myofibrils are fairly defined by the sarcoplasmic reticulum (Fig. 7). Therefore, the fibre type of both muscles can be identified positively by transverse sections.

In the central portion of the red fibre and of the white one, a few irregularly polygonal small myofibrils are surrounded by some sarcoplasm and its constituents.

The difference between a Felderstruktur and a Fibrilienstruktur as reported light- 
microscopically (KRÜGER 1949) and electronmicroscopically (PEACHEY and HuXLEY, 1962, in the frog; Hess 1965 in the garter snake) is not very clear in this fish as reported in a certain fish (Bone 1966) and in human (SHAFiQ et al. 1966).

Although the muscle fibres of this fish are found to be rather different from those of other vertebrates in the shape and disposition of the myofibrils in the transverse sections, the arrangement of myofilaments in the longitudinal and cross sections of these red and white fibres seems, in most fundamental respects, not to differ from those of other vertebrates (the rabbit by HuxLey and HANson 1960, the sea horse by Bergman 1964a, the black Mollie by Franzini-Armstrong and Porter 1964, the frog by Peachey 1965 and by Page 1965).

In the longitudinal sections of the red and white fibres, the myofibrils are tightly packed in the small amount of cytoplasm and one can recognize in the myofibrils the regular repeating pattern of myofillaments which show dense $\mathrm{Z}$ lines at the centres of the light I bands and the A bands having a central light $\mathrm{H}$ zone and a dark $\mathrm{M}$ line in the middle of the $\mathrm{H}$ zone (Fig. 8, 9). It is interesting to note that, in both fibres under higher magnification, there are thickenings of the thin myofilaments on either side of the $\mathrm{Z}$ line which are disposed to form a regular zigzag configuration as described before (KNAPPEIS and CARLSEN 1962, Franzini-Armstrong and Porter 1964) and a few fine filamentous structures linking the thick myofilaments in the distinct $M$ line seem to run perpendicularly to the fibre axis (Fig. 10). In cross sections through this $M$ line of both fibres, well defined cross-bridges similar to those reported in the fish muscle (Franzini-Armstrong and Porter 1964) and the fast muscle of the frog (PAGE 1965) are observed to connect with the thick filaments; these bridges are presumed to coincide with the above-metioned filamentous structures traversing at the M line (Fig10, 11).

At the level of the $\mathrm{Z}$ line and I band, the thick filaments are not present. The thin filaments are organized in a very regular square lattice near their insertion into the $\mathrm{Z}$ line but they are somewhat disordered far from the border of this line (Fig. 12). The typical hexagonal disposition of thin and thick filaments is seen evidently at the A band. The thick filaments constituting the $\mathrm{H}$ zone seem to be a little thiner than those in the M line (Fig. 13).

According to the comparative studies of slow and fast muscle fibres in the amphibian (Peaghey and Huxley 1962, Page 1965) and reptile (Hess 1965), the criterion for identifying a fast fibre depends on the presence of $\mathrm{M}$ lines, ordered $\mathrm{Z}$ lines and well defined H zones. Furthermore, PAGE (1966) has emphasized the presence of cross-links between thick filaments of the $\mathrm{M}$ line in the fast fibre. Similar observations in thin and thick fibres of the rat diaphragm (Forssmann and MAtTer 1966) have revealed that the thin fibres resemble the frog slow fibres and the thick its fast fibres.

In the present study, no structural differences regarding the arrangement of myofilaments are observed between small red and large white fibres; the alignment of the myofilaments is similar to that of the frog fast fibre.

The triads (Porter and Palade 1957) are located at every $Z$ line level of each myofibril in both muscle fibres unlike the cases of slow fibres (Fig. 8, 9, 12, 14). The central element of each triad (transverse tubule or $\mathrm{T}$ system) usually apears as a single tubule with slightly dense content and runs transversely around the 


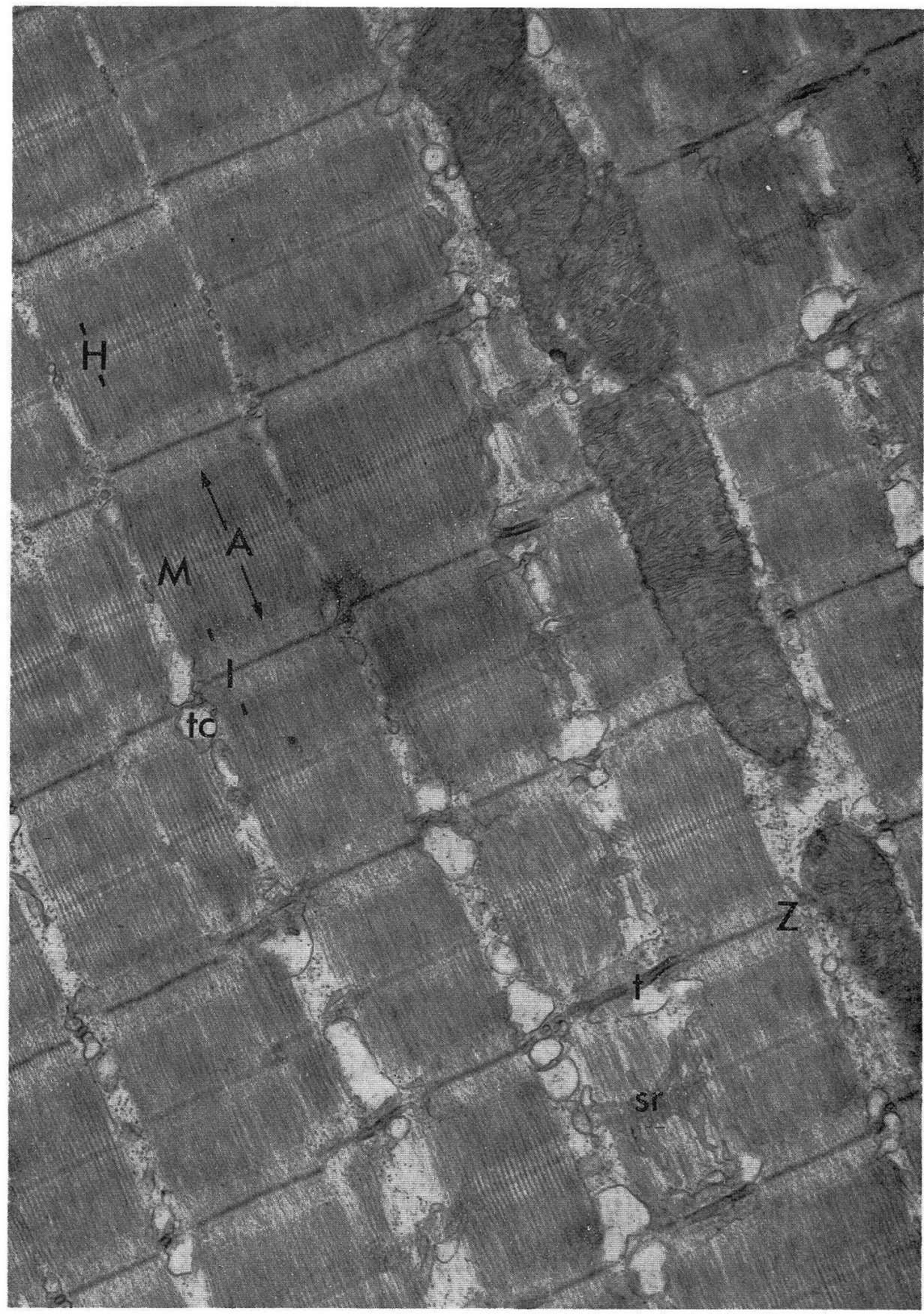

Fig. 8. Red fibre in longitudinal section. The myofibrils show a typical transverse banding pattern. A regular zigzag configuration of the $Z$ line is shown in the upper left corner of the figure. The triads $(t)$ are located at the $Z$ line $(Z)$ level. The terminal cisternae $(t c)$ are shown to be filled with a diffuse granular material. Mitochondria in the intermyofibrillar sarcoplasm show no close relationship to the banding of myofibrils. $I \mathrm{I}$ band, $A \mathrm{~A}$ band, $H \mathrm{H}$ zone, $M \mathrm{M}$ line, $s r$ sarcoplasmic reticulum. $\times 15,000$ 


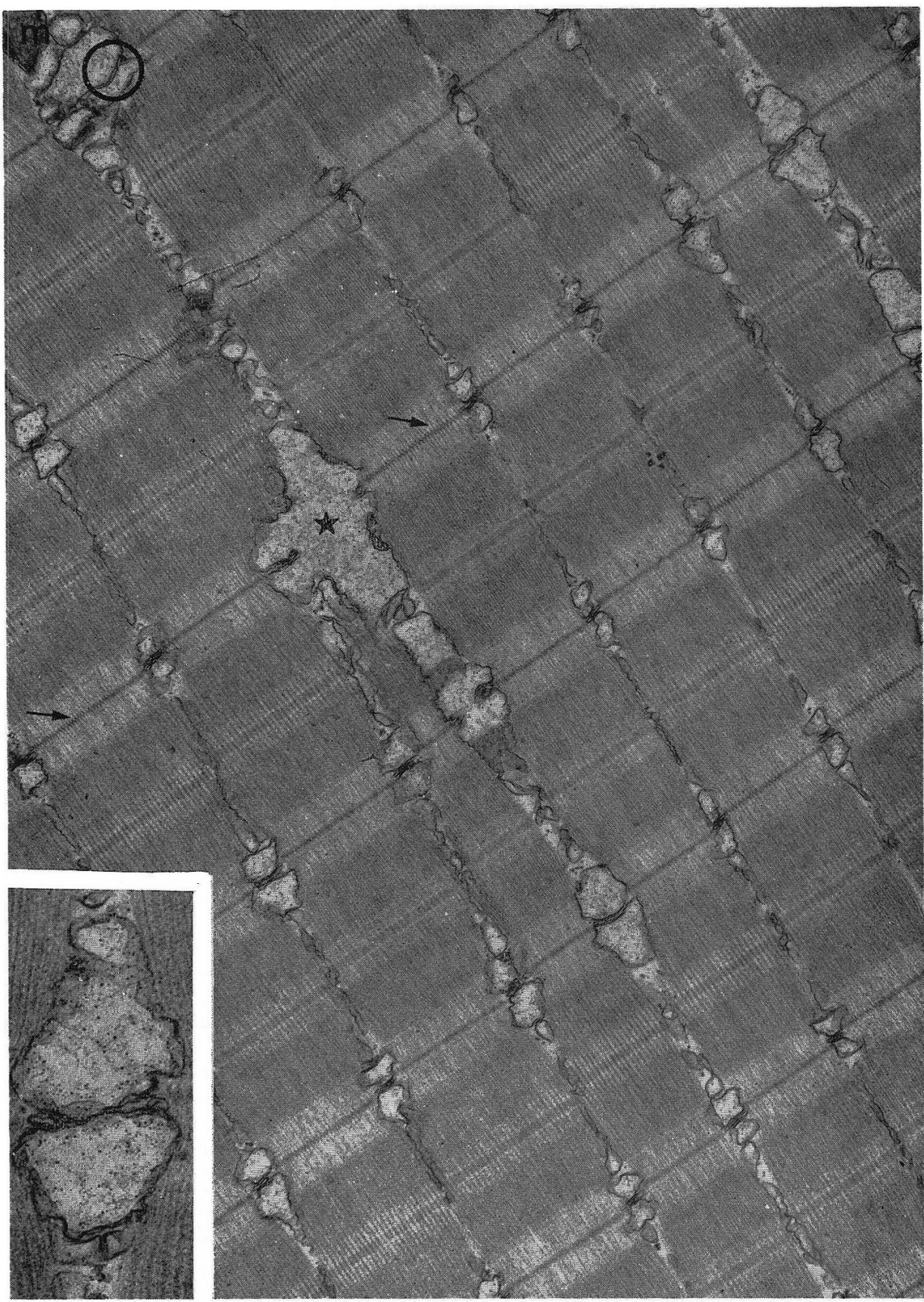

Fig. 9. White fibre in longitudinal section. See also Figure 8. In comparison with Figure 8, no fundamental differences between the two types of muscle fibres are observed as to the appearance of the transverse banding, of the sarcoplasmic reticulum and of the triads. Intermyofibrillar mitochondria $(m)$ are few. In the centre of the figure, longitudinal connections (star) between terminal cisternae on opposite sides of a $\mathrm{Z}$ line are seen. The two terminal cisternae are close to each other just forming the longitudinal connection (circle and inset). Arrows indicate the zigzag pattern of the $\mathrm{Z}$ line. $\times 19,000$. Inset : $\times 49,000$ 


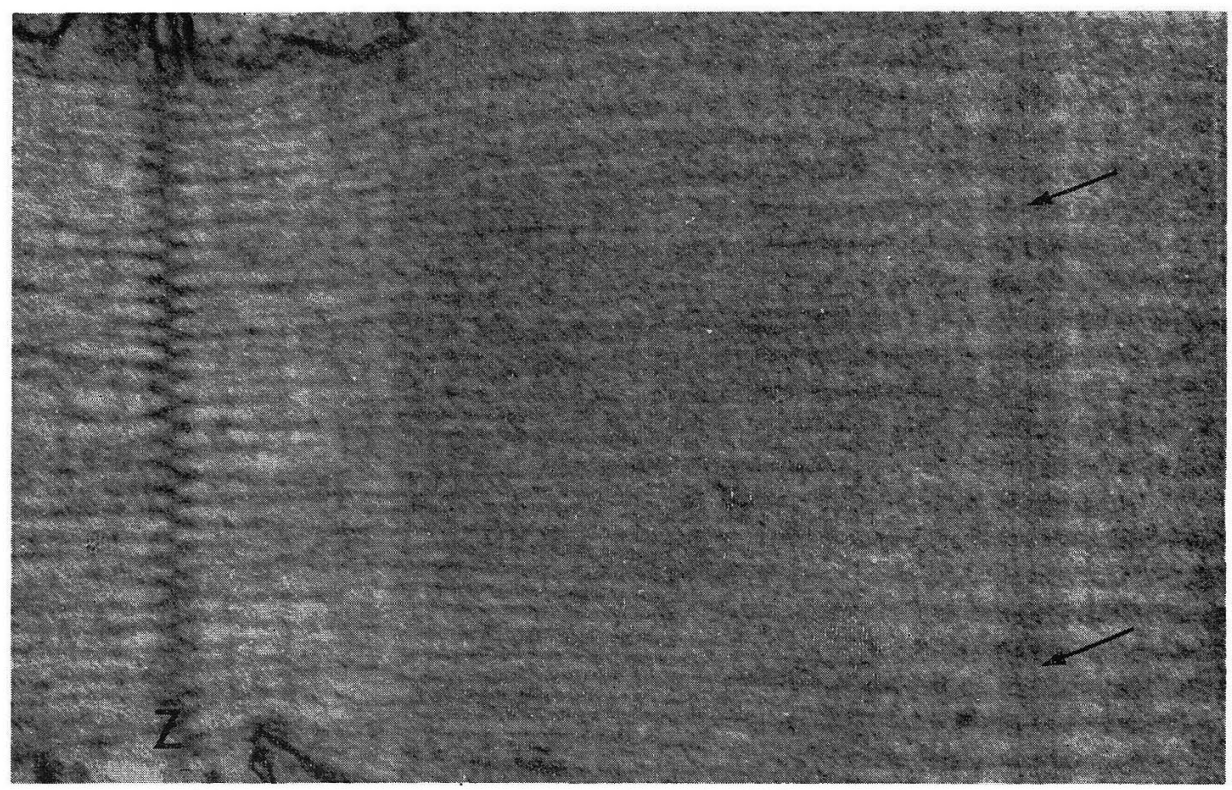

Fig. 10. White fibre in longitudinal section showing the thickening of the thin myofilaments on either side of the $\mathrm{Z}$ line $(Z)$ and the ordered spacing of them near the $\mathrm{Z}$ line. A few thin filament-

like structures (arrows) connecting the thick filaments can be seen in the $\mathrm{M}$ line. $\times 110,000$

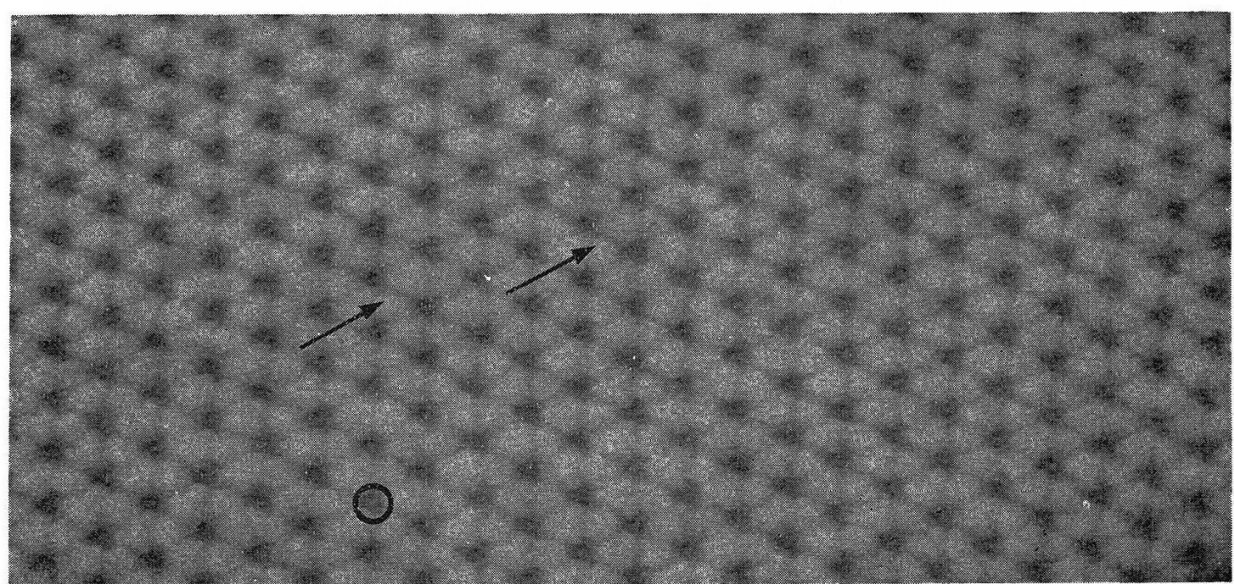

Fig. 11. White fibre in cross section through the $M$ line. Fine bridges connect the thick myofilaments at this level (arrows). The filaments appear hollow (circle). $\times 140,000$

myofibrils at the $\mathrm{Z}$ line level (Fig. 12, 14). The outer elements of the triads, the terminal cisternae (Porter and PAlAde 1957) filled with a diffuse granular material and facing the transverse tubule are dilated and then connected by longitudinal tubules. These tubules extend in a longitudinal direction and fuse to form a complex network structure at the $\mathrm{H}$ band level (Fig. 8, 9, 14). One can observe some circular or elongated fenestrations in the grazing face views of this network of the sarcoplasmic 


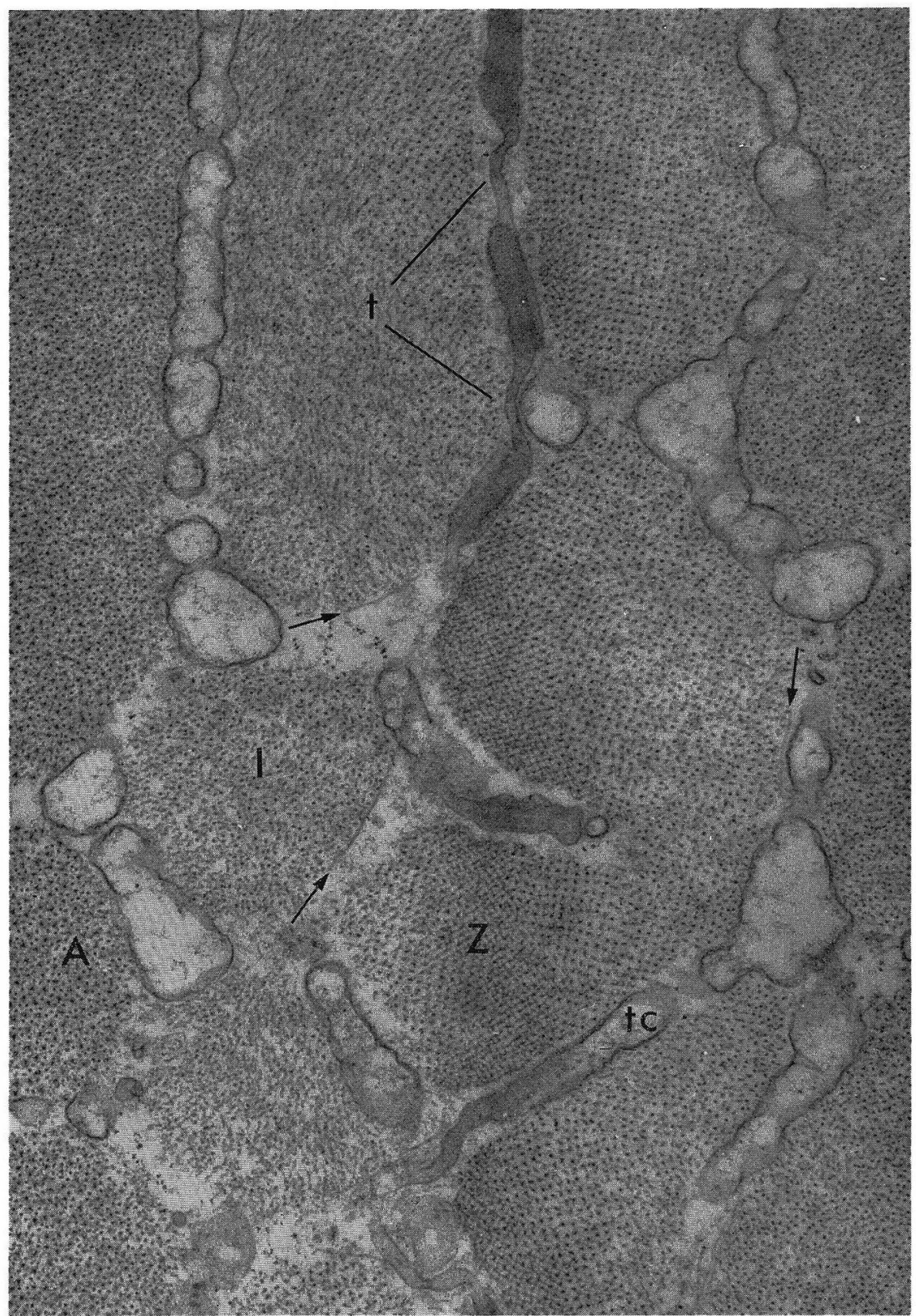

Fig. 12. Red fibre in cross section through the $\mathrm{Z}$ line $(Z)$, the I band $(I)$ and a part of the A band $(A)$ showing the different arrangement of the myofilaments in various bandings and the profils of the transverse tubule $(t)$ and the terminal cisternae $(c t)$. Note the square pattern of the thin filaments in the region of the $\mathrm{Z}$ line. Fine cytoplasmic filaments (arrows) are seen in the I band region near the $\mathrm{Z}$ line. Glutaraldehyde and osmium fixation using collidine buffer only. $\times 40,000$ 


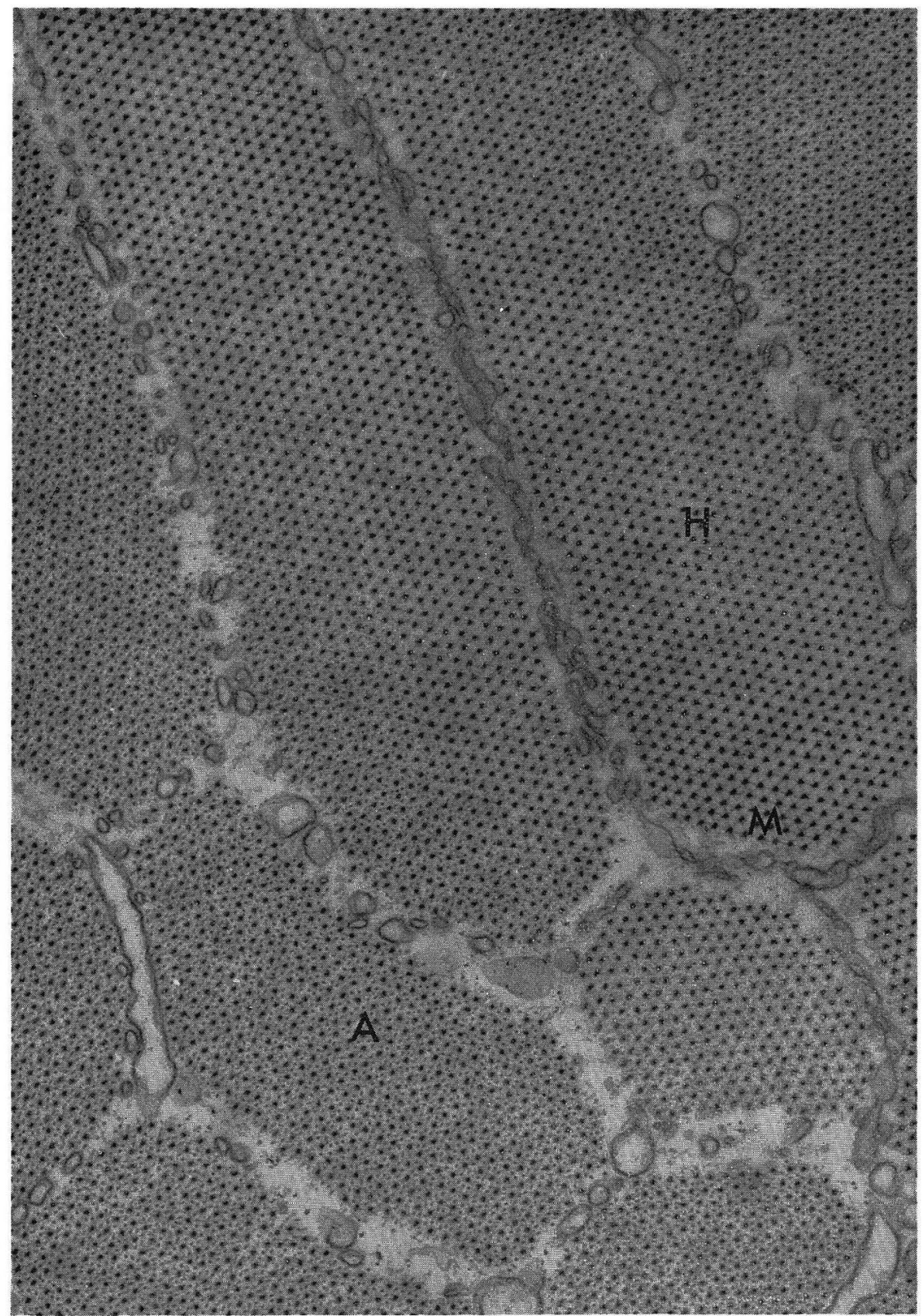

Fig. 13. Red fibre in slightly oblique section through the $\mathrm{A}$ band $(A)$, the $\mathrm{H}$ zone $(H)$ and the $\mathrm{M}$ line $(M)$. The hexagonal array of thin and thick myofilaments is seen at the $\mathrm{A}$ band. In the $\mathrm{H}$ zone and the $\mathrm{M}$ line, only the thick filaments can be seen. Close observation reveals fine cross-bridges between the thick filaments at the $M$ line. The several tubular profils of the sarcoplasmic reticulum in the A band transform to a more continuous grouping of vesicular profil at the $M$ line. $\times 40,000$ 


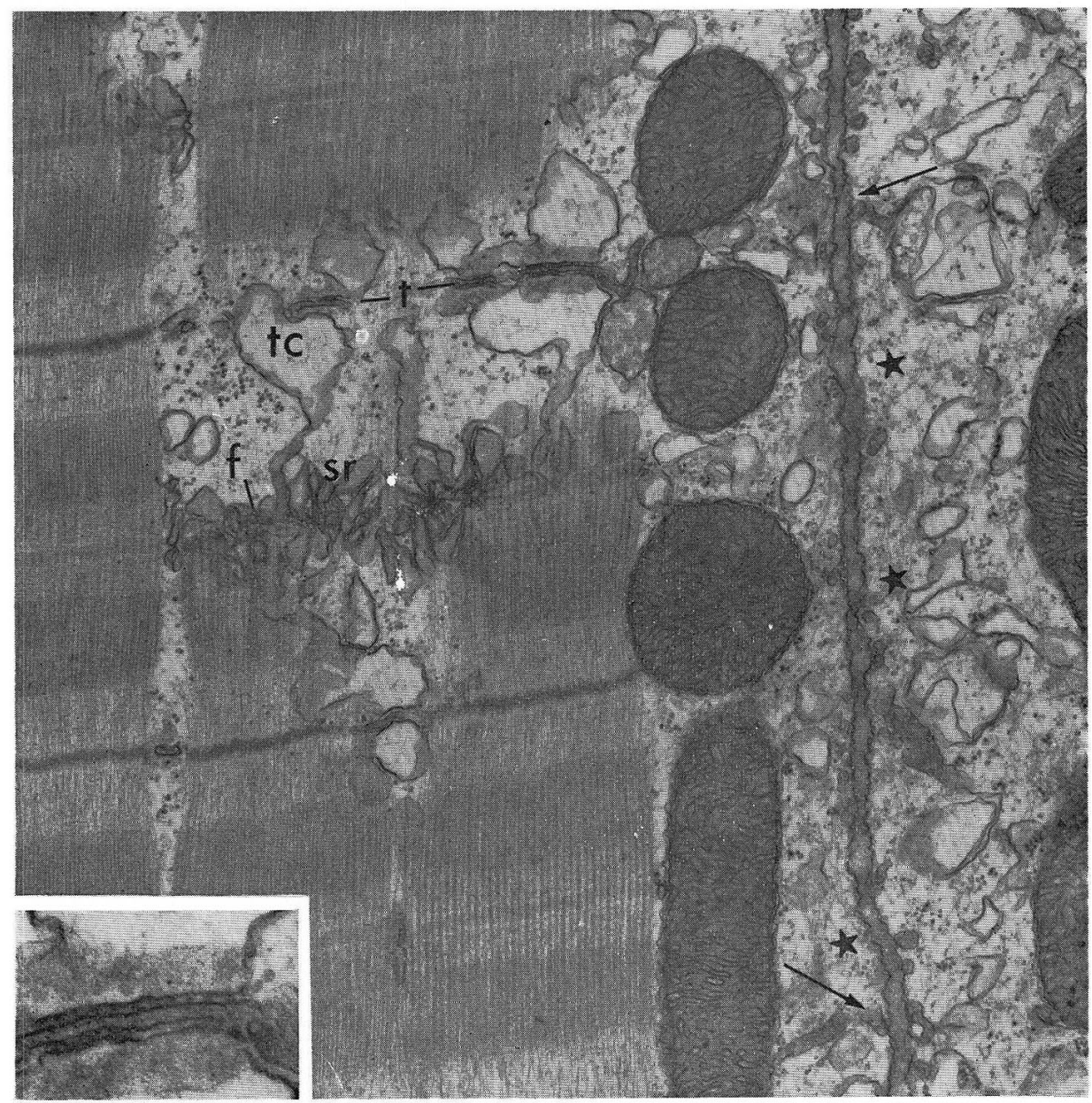

Fig. 14. Red fibre in longitudinal section showing the $\mathrm{T}$ system $(t)$ and the profile of the network of the sarcoplasmic reticulum $(s r)$. The terminal cisternae $(t c)$ are dilated sacs facing the transverse tubule. They extend longitudinally and form a complex labyrinthine structure where the fenestrations $(f)$ can be seen. The transverse tubules come close to the sarcolemma (arrows). Fine cytoplasmic filaments, running in an irregular diretion, are seen in the sarcoplasm (stars). The inset shows the triad in higher magnification. Note the bridge-like structures between the two adjacent membranes of the transverse tubule and the terminal cisterna. The content of the transverse tubule appears slightly dense. $\times 15,000$; inset : $\times 77,000$

reticulum (Fig. 14). According to Peachey (1965), this fenestratrated area called fenestrated collar may be regarded not as a connection between the internal content of the sarcoplasmic reticulum and the sarcoplasm but rather continuous through the pore with the sarcoplasm adjacent to the next myofibril.

The distance between the terminal cisternae and transverse tubules is about $200 \AA$ and there are small uniformly spaced bridge-like structures (Fig. 14. inset) as reported in the bat by Revel (1962) and in the frog by Peachey (1965) but not tight junction (Fahrendagir 1965, Cheng and Breinin 1966) or desmosome-like adhesion, 
(WoLfF 1966).

Usually the two terminal cisternae of the same triad are interrupted at the $\mathrm{Z}$ line but occasionally are found to be continuous from one sarcomere to the next (Fig. 9) as reported before (Porter and Palade 1957, Peachey 1965, Page 1965). In other places, they are very close to each other without investing the transverse tubule; and the longitudinal connection between the terminal cisternae arises at those places probably by the fusing of the two adjacent membranes of cisternae (Fig. 9 inset). Thus, as to the appearance of the sarcoplasmic reticulum, no fundamental differences between the red and white fibres could be detected. The $\mathrm{T}$ system has been demonstrated to be a sarcolemmal derivative and continuous to the extracellular space (Franzini-Armstrong and Porter 1964, Huxley 1964). Its possible function has been considered as a conduction of excitation into the interior of the fibre (PorTer 1961). Unfortunately, an actual continuity between the functionally important $\mathrm{T}$ systcm and the sarcolemma of the muscle fibres has not been found in the crucian carp. But the transverse tubules are seen to come close to the sarcolemma in both fibres of this fish (Fig. 14, 15).

It has been reported that in the fast muscle fibres from the swim-bladder of the toad fish (FAwcett and REvel 1961), from the bat cricothyroid muscle (REveL 1962) and from the segmental muscle of the garter snake (Hess 1965), the $\mathrm{T}$ system is present at two levels of the sarcomere, namely at the A-I junctoins but in frog fast fibres (PAGE 1965) it lies at the level of the $Z$ line. Moreover, another striking feature of these fast muscles is the abundance of the elements of the sarcoplasmic reticulum. In contrast, the saroplasmic reticulum of the slow fibres is poorly developed and the triad of them is completely absent (PEACHEY and Huxley 1962, Hess 1965) or only rarely found (PAGE 1965). IIowever, the sarcoplasmic reticulum in the rat diaphragm

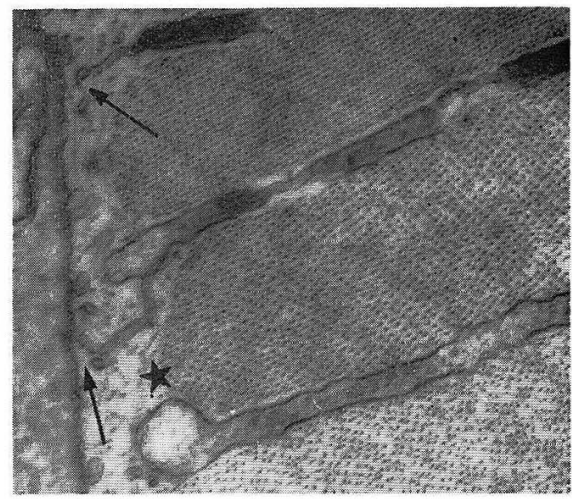

Fig. 15. White fibre in transverse section through the $\mathrm{Z}$ line and the I band showing the approach of the transverse tubules to the sarcolemma (arrows). Fine cytoplasmic filaments in the sarcoplasm are also seen (star). $\times 24,000$ does not show distinctive differences in structure between small and large muscle fibres (Forssmann and Matter 1966, WolfF 1966).

Concerning the development of the sarcoplasmic reticulum and the location of the triad in the crucian carp, no structural differences between red and white fibres are observed and their sarcoplasmic reticulum is thought to be well developed in both fibres. Therefore, in many respects, both red and white fibres of this fish correspond to the fast fibres of the frog.

In the red fibres mitochondria of varying size are, apart from the subsarcolemmal accumulation, seen in the intermyofibrillar sarcoplasm and do not show a close relationship to the banding of myofibrils; they are not so richly distributed as in certain fast acting muscles (FAwcett and Revel 1961, Revel 1962, Bergman 1964 a, Gauthier and Padykula 1966) (Fig. 4, ४). In the white fibres, however, mito- 
chondrial content among the myofibrils is usually low as is beneath the sarcolemma (Fig. 9).

At the neuromuscular junctions of both fibres, the moter nerve endings, several of which occur on an individual fibre, are oval or spherical in shape and fit into smooth depressions in each muscle fibre (Fig. 16, 17). The terminals contain mitochondria, synaptic vesicles and very few cored vesicles. The postjunctional sarcolemma lacks the infoldings which are present in frog fast fibres. The findings of this nerve termination are similar to those in other fishes (NAKAJima 1962, BERGMAN

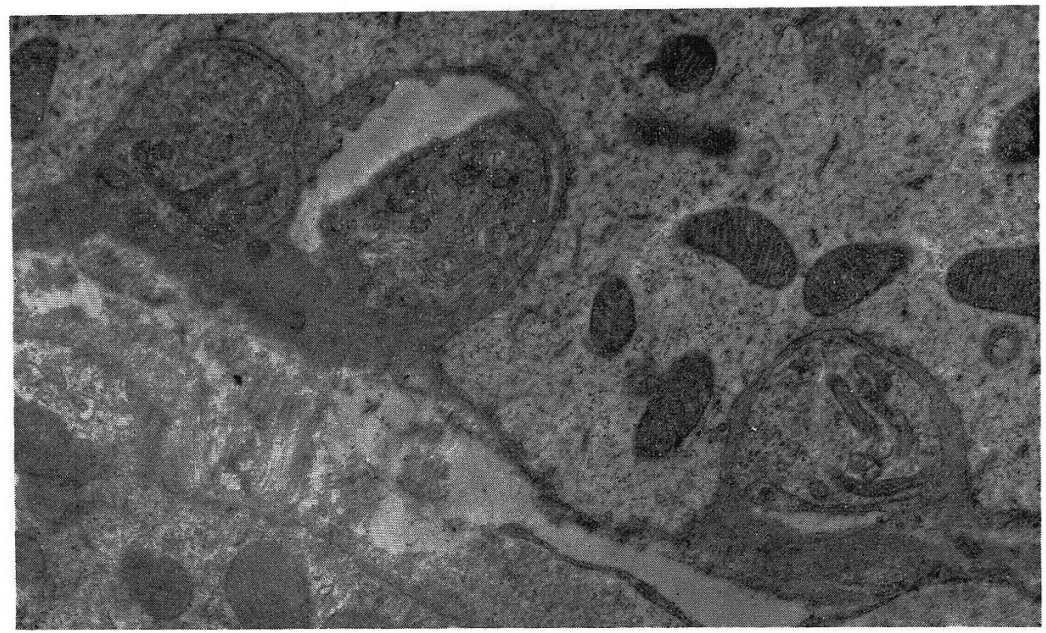

Fig. 16. Three nerve endings on the red fibre. They are so called en grappe terminals. Under the terminals, the postjunctional sarcolemma does not show the typical infoldings found in the frog fast fibres. Sarcolemmal depressions are slightly deeper than in the white fibre. The red fibres are richly innervated. $\times 10,000$

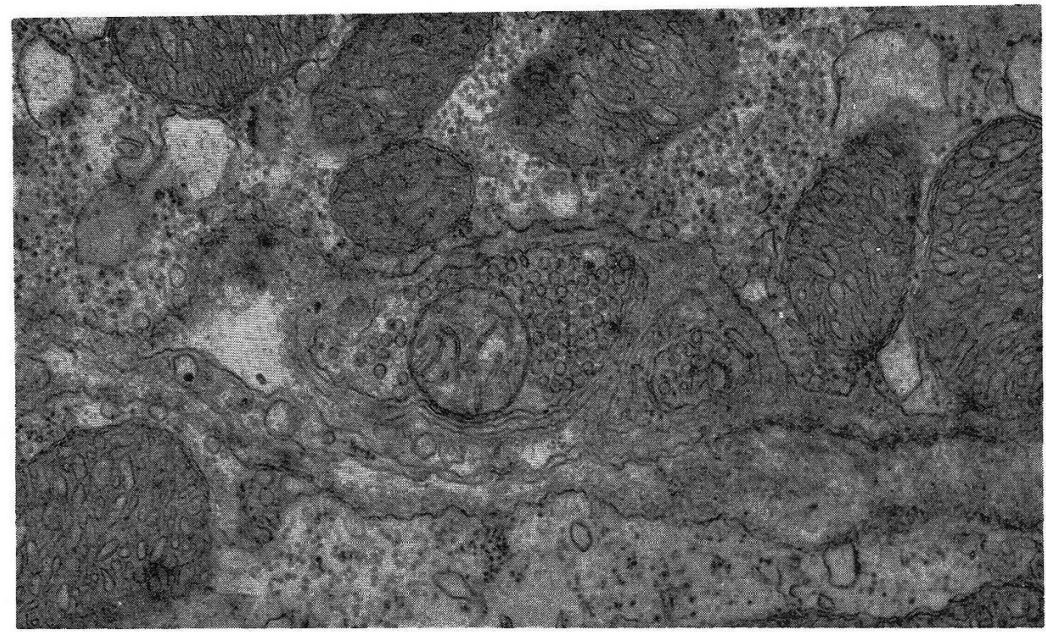

Fig. 17. A nerve ending on the white fibre. This is also of an en grappe type though the distribution of the terminals is not so abundant. $\times 26,000$ 
$1964 \mathrm{a}, 1967)$ and the frog and snake slow fibres (Hess 1965, PAGE 1965).

The fast muscle fibre possesses a single nerve ending which can be recognized by its highly folded postjunctional sarcolemma (Hess 1965). This type of nerve ending has been called the en plaque type. The slow muscle fibre, on the other hand, has multiple motor nerve endings along its length (Hess 1965, PAGE 1965). The extensive postjunctional folds of the sarcolemma under the nerve endings are rather scarce. This type of nerve endings has been named the en grappe type.

The observation in the present work indicates that both red and white muscle fibres of the crucian carp have multiple motor nerve endings of the en grappe type.

On the distribution of nerve terminals, the densely grouped terminals in some areas of the fibre surface and the slightly deepened sarcolemmal depressions are often

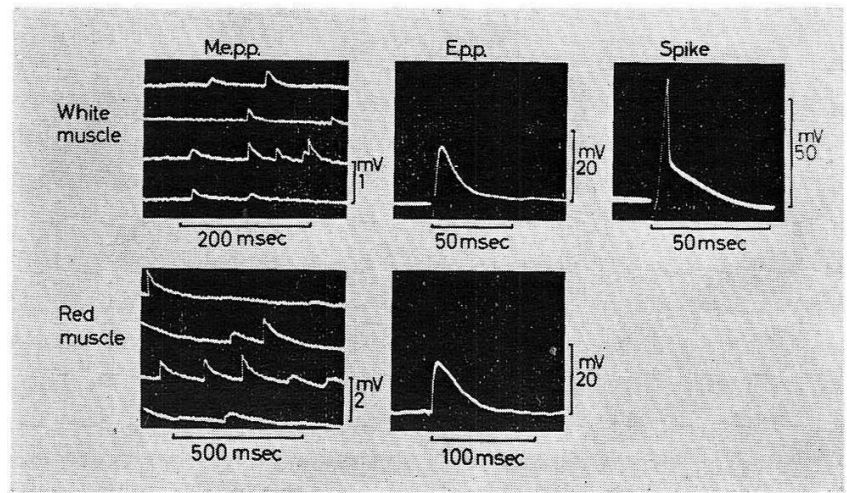

Fig. 18. The intracellular records of miniature end-plate potentials (MEEPs), end-plate potentials (EPPs) and action potential from both red and white muscles. The MEEPs and the EPPs can be recorded along the entire length of both muscle fibres. Action potentials are generated in the white fibres but very rarely in the red. The figure was provided by Drs. Hidaka and Torda with their courtesy.

observed particularly in the red fibres. Therefore, the types of innervation might be classified as multi-focal diffuse innervation in the red fibres and mono-focal diffuse innervation in the white ones.

As a matter of fact, these morphological observations have been confirmed by electrophysiological findings. According to Hidaka and Toida (1967 b), the histograms of the amplitude and the interval of the spontaneous miniature endplate potentials (MEPPs) in both muscle fibres have shown skew curve; i. e. this fact should indicate that the innervation to each muscle fibres are diffuse. Hidaka and Toida (1967 b) also have proved the

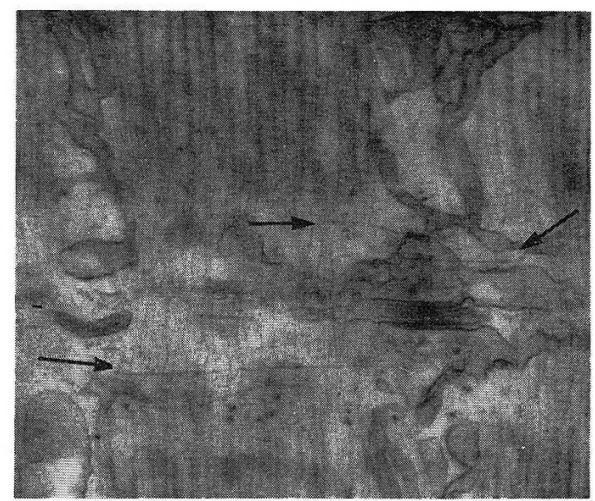

Fig. 19. Red muscle in longitudinal section. At the $\mathrm{Z}$ line level and the $\mathrm{I}$ band region, one can see several fine cytoplasmic filaments running transversely or slightly obliquely to the

long axis of the fibre (arrows). $\times 30,000$ 
differences in innervation between these red and white muscles by the distribution of the end-plate potentials (EPPs) along single muscle fibres (Fig. 18).

Although not pertinent to the main subject of this paper, fine cytoplasmic filaments, about $50 \AA$ in diameter, other than well known contractile filaments, can be sometimes found in the muscles of this fish (Fig. 12, 14, 15, 19). They are present in an irregular direction at the subsarcolemmal region or run transversely to the fibre axis at the I band level close to the $Z$ line. The filaments are scanty in number and variable in length. These findings are similar to those described in the cardiac muscle of the goldfish (YАмамото 1967) and in mammals (SANDBoRn et al. 1967) but seem to differ from filamentous aggregates reported in the bat (REveL 1967) or from the mass of degenerated filaments in humans (SHAFiQ et al. 1966).

\section{Discussion}

It is clear from the above observations that the red pectoral fin muscle and the white abdominal fin muscle of the crucian carp differ in the diameter of fibres, in the number of mitochondria, in the amount of glycogen and fats, in the supply of capillaries and in the disposition of myofibrils of the transverse sections. These features resemble those described as the differences between red and white muscles of many animals (Smith and Giovacahini 1956, Porter and Palade 1957, Padykula and Gauthier 1963, Franzini-Armstrong and Porter 1964, Bone 1966, Gauthier and Padykula 1966 and others). Particularly the difference of the mitochondrial content between both fibres is most conspicuous. Padykula and Gauthier (1963) identified the fibre types of rat diaphragm in cytological preparations which demonstrate mitochondria. From this point of view, these two kinds of muscle fibres of this fish can be distinguished into red and white fibre.

The red pectoral fin muscle may be called a mitochondria-loaded muscle or a glycogen-loaded one.

The study of the distribution pattern of the different fibre types in a skeletal muscle in mammals (Tsukamoто and Mori 1966) showed that white fibres were numerous in the superficial part of the muscle, whereas red and intermediate fibres occurred in the interior portion of them. Whether the fish muscles of the different types of fibre in the present study are the mixed muscle or not, is unsettled but as far as has been observed, the superficial portion of the pectoral fin muscle is probably constituted only with red fibres and that of the abdominal fin muscle is composed only of white fibres.

The most significant result of this study may be the demonstration that, in spite of the different electrophysiological properties of the two kinds of muscles of the crucian carp, the structure of the myofibrils and the sarcoplasmic reticulum and the location of the triads in both muscles are not distinguishable and that the innervation of both muscles resembles that of the slow fibres of the frog. Moreover, the internal structure of both muscle fibres is similar to that of the fast fibres of the frog.

Recently Hess (1966) noted similar findings from the striated muscle of the avian iris but the physiological properties of the muscle fibres and the motor nerve endings have not been determined. Based on the present study, a muscle fibre with the en grappe type of nerve endings is not always a slow fibre but it is innervated diffusely. 
Although the reciprocation between the structure and function of the avian iris muscle is uncertain, the innervation of the avian iris muscle may be thought to be diffuse.

Adrian and Peachey (1965) described the twitch and slow fibres from the frog as having a membrane capacitance per unit surface area about 3 times larger in the fast fibres than in the slow fibres. They correlated well these observations with the morphological features of both tissues in view of the different morphology of the sarcoplasmic reticulum in twitch and slow fibres. According to Hidaka and Toida (1967 a), the electrophysiological characteristics of the membrane in red and white muscle are quite different; for example, the resting potentials are $74.8 \mathrm{mV}$ for the red fibre and $83.3 \mathrm{mV}$ for the white. Furthermore, the membrane capacitance is $2.55 \mu \mathrm{F} / \mathrm{cm}^{2}$ for the red and $7.23 \mu \mathrm{F} / \mathrm{cm}^{2}$ for the white. These electrophysiological results show that the membrane capacitance of the fish red and white muscle fibres generally resemble those of the frog slow and twitch fibres. Therefore, the morphological features of the present study have no correlation with the electrophysiological characteristics of the membrane in red and white muscles whose sarcoplasmic reticula are equally developed.

On the other hand, the rate of the tension development is higher in the white muscle than in the red muscle and fatigues of the twitch tension and tetanus in the white muscle appear much earlier than those of the red muscle (HIDAKa and Toida 1967 b). Another point of interest, Gauthier and Padykula (1966) concluded that the small red fibres of mammalian diaphragm are characterized by a high metabolic rate and fast rate of breathing. The red muscle of this fish may be thought to have a high metabolic rate, because of high content of mitochondria and glycogen, rich supply of capillary and tolerance for fatigues of the twich tension. It has been described that the principal functions of the pectoral and abdominal fins seem to be for such maneuvers as climbing and diving, banking, turning and stopping in the water. For these actions, the pectorals are the major organs and the abdominals, the accessory ones (LAgler, Bardach and Miller 1962). Therefore, it is of interest to suppose that the red pectoral fin muscle is used for continuous movement to maneuver and the white abdominal one for momentary maneuvering to assist the pectoral as a secondary organ.

\section{Summary}

The M. levator pinnae pectoralis of Carassius auratus appeared red and the M. levator pinnae lateralis abdominis pale to the naked eye. The fine structure of both these muscles were observed to correlate with the recent electrophysiological findings gained in the same material.

The average diameter of both fibres was $36.0 \mu$ for the red fibres and $49.4 \mu$ for the white ones.

The fibre type of both these muscles can be clearly identified by the examination of transverse sections. In the red fibres, the mitochondrial accumulation beneath the sarcolemma and rich deposits of glycogen were seen. The peripheral myofibrils of both tissues appeared in ribbon-like forms in a radial direction but almost all inner fibrils were polygonal in the red fibres.

Regarding the arrangement of the myofilaments, no differences between the red 
and white fibres were observed. The $\mathrm{Z}, \mathrm{I}, \mathrm{A}, \mathrm{H}$ and $\mathrm{M}$ bands were found to be well delineated. The $\mathrm{Z}$ lines were disposed to form a regular zigzag configuration and at the $M$ lines well defined cross-bridges between the thick myofilaments were seen. The triads were located at the $\mathrm{Z}$ line level and the sarcoplasmic reticulum was well developed. In short, the internal structure of these two kinds of muscle was similar to that of the fast fibres of the frog.

On the other hand, the innervation of both these muscles resembled that of the slow fibres of the frog; they showed the diffuse innervation. The nerve endings of both muscle fibres were so-called "en grappe" type. In the red fibres, densely grouped terminals in some areas of the fibre surface were found. The types of innervation might be classified as multi-focal diffuse innervation in the red fibre and mono-focal diffuse innervation in the white. These differences were confirmed by electrophysiological findings.

The electrophysiological properties of the red fibres showed a tendency to be similar to the slow fibres of the frog and the white fibres to the fast fibres of the frog. However, the morphological differences between the fast and slow fibres in the frog could not be recognized in the muscles of this fish.

Acknowledgements. The author expresses his thanks to Prof. Dr. E. Yamada for his kind guidance and constant encouragement and to Prof. Dr. H. Kuriyama and Dr. T. Hidaka (Department of Physiology, Kyushu University) for their valuable advice and suggestions.

\section{魚の赤筋と白筋の微細構造について（内容自抄）}

フナの胸ひれ挙筋，腹ひれ挙筋は肉眼的には前者は赤筋であり，後者は白筋である.両 者の生理学的特性については詳細に調べられているので，それと形態学的所見との対比を 試みるために，乙の両筋の微細構造を電子顕微鏡で観察した。

筋の平均直径は 赤筋が $36.0 \mu$, 白筋が $49.4 \mu$ であつた。

両者の筋型の差は横断像の観察により明瞭に示され，赤筋では筋鞘直下にミトコンドリ アの集団が著明で，グリコーゲンなども多い．筋原線維は両筋とも筋細胞辺縁部ではリボ ン様放射状に配列するが, 赤筋ではほとんどの筋原線維が不規則多角形の横断像を示した。 筋細線維の配列に関しては，両筋に構造上の差はほとんどなく，明瞭な Z, I, A , H お よび $\mathrm{M}$ 帯を観察した。とくに Z 線は規則的なジグザグ模様を示し， $\mathrm{M}$ 線では $\mathrm{A}$ 線維間を 連結する橋状構造があつた，Triad は Z 線レベルにあり， sarcoplasmic reticulum の発 達は良好であつた。換言すれば，両筋とも筋の内部構造は従来知られているカエルの速筋 と似ている。

両筋の神経支配はカエルの遅筋のそれと類似しており，多重支配である，神経終末はい わゆる “en grappe” 型であつたが，赤筋ではこの終末の分布が密で，神経支配形式は multi-focal diffuse innervation, 白筋では mono-focal diffuse innervation と推察され

る. この事実は生理学的に屯証明されている.

赤筋の生理学的特性は カエルの遲筋の傾向を示し，白筋はカエルの速筋の傾向を示す が，フナの赤筋と白筋では，カエルの遅筋と速筋で示されたような形態学的な差は認めら れなかつた。 


\section{References}

Adrian, R. H. and L. D. Peachey : The membrane capacity of frog twitch and slow muscle fibres. J. Physiol. 181 : 324-336 (1965).

Andersen, P., J. K. S. Jansen and Y. Loyning: Slow and fast muscle fibres in the atlantic hagfish. Acta physiol. scand. 57:167-179 (1963).

Andersson-Gedergren, E.: Ultrastructure of motor endplate and sarcoplasmic components of mouse skeletal muscle fiber as revealed by three-dimentional reconstructions from serial sections. $\mathrm{J}$. Ultratr. Res., suppl. $1: 1-191$ (1959).

Bennett, H. S. and J. H. Luft : s-Collidine as a basis for buffering fixatives. J. biophys. biochem. Cytol. $6: 113-114$ (1959).

Bergman, R. A.: The structure of the dorsal fin musculature of the marine teleosts, Hippocampus hudosonius and H. zosterae. Bull. Johns Hopkins Hosp. 114:325-343 (1964 a).

: Mechanical properties of the dorsal fin musculature of the marine teleost, Hippocampus hudsonius. Bull. Johns Hopkins Hosp. 114 : 344-353 (1964 b).

: Moter nerve endings of twitch muscle fibres in Hippocampus hudsonius. J. Cell Biol. 32 : 751757 (1967).

Bone, Q.: On the function of the two types of myotomal muscle fibre in elasmobranch fish. J. Mar. Biol. Ass. U. K. 46 : 321-349 (1966).

Cheng, K. and G, M. Breinin : A comparison of the fine structure of extraocular and interosseus muscles in the monkey. Invest. Ophthalmol. 5 : 535-549 (1966).

Denny-Brown, D. E.: The histological features of striped muscle in relation to its functional activity. Proc. Roy. Soc. London, B. 104 : 371-411 (1929).

Dubowitz, V. and A. G. E. Pearse : A comparative histochemical study of oxidative enzyme and phosphorylase activity in skeletal muscle. Histochemie 2:105-117 (1960).

Fahrenbach, W. H.: Sarcoplasmic reticulum: Ultrastructure of the triadic junction. Science 147 : 1308-1310 (1965).

Fawcett, D. W. and J. P. Revel : The sarcoplasmic reticulum of a fast-acting fish muscle. J. biophys. biochem. Cytol. 10 : No.4, suppl. 89-109 (1961).

Flood, P. R. and J. Storm Mathisen : A third type of muscle fibre in the parietal muscle of the atlantic hagfish Myxine glutinosa L.Z.Zellforsch. 58 :638-640 (1962).

Forssmann, W. G. and A. Matter : Ultrastruktureller Nachweis von zwei Myofibrillentypen in den Muskelfasern des Rattenzwerchfells. Experientia. 22 : 816-817 (1966).

Franzini-Armstrong C. and K. R. Porter: The $Z$ disc of skeletal muscle fibrils. Z. Zellforsch. $61: 661-672(1964)$. Cell Biol. 22 : 675-696 (1964).

Gauthier, G. F. and H. A. Padykula : Cytological studies of fiber types in skeletal muscle. A comparative study of the mammalian diaphragm. J. Cell Biol. $28: 333-354$ (1966).

Hagiwara, S. and K. Takahashi : Resting and spike potentials of skeletal muscle fibres of salt-water elasmobranch and teleost fish. J. Physiol. 190 : 499-518 (1967).

Hess, A.: The structure of slow and fast extrafusal muscle fibers in the extraocular muscles and their nerve endings in guinea pigs. J. cell. comp. Physiol. 58:63-80 (1961).

: The sarcoplasmic reticulum, the $\mathrm{T}$ system, and the motor terminals of slow and twitch muscle fibers in the garter snake. J. Cell Biol. 26:467-476 (1965).

: The fine structure of the striated muscle fibers and their nerve terminals in the avian iris: Morphological "twitch-slow" fibers. Anat. Rec. $154: 357$ (1966).

Hess, A. and G. Pillar: Slow fibres in the extraocular muscles of the cat. J. Physiol. 169: 780-798 (1963).

Hidaka, T. and H. Kuriyama : Effects of catecholamines on the cholinergie neuromuscular transmission in fish red muscle. J. Physiol. (1967, in press). 
Hidaka, T. and N. Toida : Biophysical properties of the red muscle fibre in the fish. J. Physiol. (1967a, in press).

: Electrophysiological observations on the motor innervation of the red muscle in the fish. J. Physiol. (1967 b, in press).

Huxley, H. E. : Evidence for continuity between the central elements of the triads and extracellular space in frog sartorius muscle. Nature $202: 1067-1071$ (1964).

Huxley, H. E. and J. Hanson : The molecular basis of contraction in cross-striated muscles. In : (ed. by) G. H. Bourne: The structure and function of muscle. New York. Academic Press, 1960. (Vol. $1: 183-227)$.

Karnovsky, M. J.: A formaldehyde-glutaraldehyde fixative of high osmolarity for use in electron microscopy. J. Cell Biol. 27 :137A-138A (1965).

Knappeis, G. G. and F. Garlsen : The ultrastructure of the $Z$ disc in skeletal muscle. J. Cell Biol. $13: 323-335$ (1962).

Krüger, P.: Die Innervation der tetanischen und tonischen Fasern der quergestreiften Skeletalmuskulatur der Wirbeltiere. Anat. Anz. $97: 169-175$ (1949).

Kuffler, S. W. and E. M. Vaughan Williams : Small nerve junctional potentials. The distribution of small motor nerves to frog skeletal muscle, and the membrane characteristics of thc fibres they innervate. J. Physiol. $121: 289-317$ (1953).

Kühne, W.: Über den Farbstoff der Muskeln. Virchows Arch. pathol. Anat. 33: 79-94 (1865).

Lagler, K. F., J. E. Bardach and R. R. Miller : Ichthyology. New York, John Wiley and Sons, 1962.

Luft, J. H. : Improvements in epoxy resin embedding methods. J. biophys. biochem. Cytol. 9 : 409414 (1961).

Mercer, E. H. and M. S. G. Birbeck : Electron microscopy. A handbook for hiologists. 2nd ed., Oxford, Blackwell Scientific Publications. 1966.

Nachmias, V. T. and H. A. Padykula : A histochemical study of normal and denervated red and white muscles of the rat. J. biophys. biochem. Cytol. $4: 47-54$ (1958).

Nakajima, Y.: Fine structure of red and white muscle fibers and their neuromuscular junction of the snake fish. In: (ed. by) S. S. Breese, jr.: Proc. 5th. Int. Congr. Electron Microscopy. New York, Academic Press, 1962. (Vol. 2, U-10)

Needham, D. M. : Red and white muscle. Physiol. Rev. 6 : 1-27 (1926).

Ogata, T. and M. Mori : Histochemical study of oxidative enzymes in vertebrate muscles. J. Histochem. Gytochem. 12:171-182 (1964).

Padykula, H. A. and G. F. Gauthier: Cytochemical studies of adenosine triphosphatases in skeletal muscle fibres. J. Cell Biol. $18: 87-107$ (1963).

Page, S. A.: A comparision of the fine structures of frog slow and twitch muscle fibres. J. Cell Biol. $26: 477-497$ (1965).

Peachey, L. D.: The sarcoplasmic reticulum and transverse tubules of the frog's sartorius. J. Cell Biol. 25 : 209-231 (1965).

Peachey, L. D. and A. F. Huxley : Structural identification of twitch and slow striated musele fibers of the frog. J. Cell Biol. $13: 177-180$ (1962).

Porter, K. R.: The sarcopalasmic reticulum. Its recent history and present status. J. biophys. biochem. Cytol. 10 : suppl. 219-226 (1961).

Porter, K. R. and G. E. Palade : Studies on the endoplasmic reticulum. III. Its form and distribution in striated muscle cells. J. biophys. biochem. Cytol. $3: 269-300$ (1957).

Ranvier, L. A.: De quelques faits relatifs à l'histologie et à la physiologie des muscles striés. Arch. Physiol. norm. Pathol. 6:1-15 (1874).

Revel, J. P.: The sarcoplasmic reticulum of the bat cricothyroid muscle. 'J. Cell Biol. 12;571-588 (1962).

Sandborn, E. B., M. G. Gôtê., J. Reberge and P. Bois : Microtubules et filaments cytoplasmiques dans le musele de mammifères. J. Microsc. $6: 169-178$ (1967). 
Shafiq, S. A., M. Gorycki, L. Goldstone and A. T. Milhorat: Fine structure of fiber types in normal human muscle. Anat. Rec. $156: 283-302$ (1966).

Smith, R. D. and R. P. Giovacchini : The vascularity of some red and white muscles of the rabbit. Acta anat. $28: 342-358$ (1956).

Stein, J. M. and H. A. Padykula : Histochemical classification of individual skeletal muscle fibers of the rat. Amer. J. Anat. $110: 103-124$ (1962).

Takeuchi, A.: Neuromuscular transmission of fish skeletal muscles investigated with intracellular microelectrode. J. cell. comp. Physiol. 54 : 211-220 (1959).

Tsukamoto, S. and M. Mori : Distribution of muscle fibres of three types differentiated by succinic dehydrogenase activity in the skeletal muscle. Arch. histol. jap. $26: 329-339$ (1966).

Wolff. H. H.: Über den Einfluß der Fixierung auf die elektronenmikroskopische Darstellung der Muskelfasern des Rattendiaphragmas. Z. Zellforsch. 73 : 192-204 (1966).

Wood, R. L. and J. H. Luft : The influence of buffer systems on fixation with osmium tetroxide. J. Ultrastr. Res. $12: 22-45$ (1965).

Yamamoto, T.: A method of toluidine blue stain for epoxy embedded tissues for light microscopy. (In Japanese with English summary.) Acta anat. nippon. 38: 124-128 (1963).

: Observations on the fine structure of the cardiac muscle cells in goldfish (Carassius auratus). In: (ed. by) T. Sano, V. Mizuhira and K. Matsuda : Electrophysiology and ultrastructure of the heart. Tokyo Bunkodo Co. 1967 (p. 1-13). 